\title{
PEMBERDAYAAN EKONOMI FAKIR MISKIN DALAM PERSPEKTIF AL-QUR'AN
}

\author{
Dede Rodin
}

\begin{abstract}
Abstrak
Kaum fakir dan miskin adalah dua kelompok kaum lemah (dhu'afa) yang banyak disebutkan Al-Qur'an. Ketika Al-Qur'an berbicara tentang kedua kelompok tersebut umumnya dalam konteks bagaimana mengentaskan kemiskinan yang mereka hadapi. Dari telaah atas ayat-ayat Al-Qur'an tentang pemberdayaan fakir miskin diperoleh kesimpulan bahwa upaya pengentasan kemiskinan dan pemberdayaan kaum fakir dan miskin menurut Al-Qur'an terkait dengan pemanfaatan dan distribusi harta. Ayat-ayat Al-Qur'an yang berbicara tentang harta ada yang berupa perintah dan anjuran dan yang kedua berupa larangan. Dari dua ketentuan ini, Al-Quran menempub beberapa model langkah untuk pemberdayaan fakir miskin, yaitu perintah bekerja, perintah memberi makanan pokok, perintah berinfak, perintah mengeluarkan zakat, pemberian dari sebagian harta warisan, pembagian ganimah dan fa'i, larangan monopoli (ibtikär) dan menimbun harta (iktināa). Beberapa model pemberdayaan di atas dapat dibagi menjadi dua kelompok; langkahlangkah yang bersifat struktural dan yang bersifat kultural. Langkah struktural lebih ditekankan kepada lembaga khusus yang menanganinya agar berjalan dengan baik, sedangkan langkah kultural lebih ditekankan pada individu, baik individu yang diharapkan menjadi salah satu subjek pengentasan kemiskinan dan pemberdayaan kaum fakir dan miskin maupun yang menjadi objeknya. Pada langkah struktural maupun kultural, keterlibatan pemerintah sangat diperlukan, bahkan dipandang sebagai sebuah keniscayaan.
\end{abstract}

Kata kunci: fakir, miskin, pengentasan, pemberdayaan,

\section{Pendahuluan}

Dalam literatur modern, masalah kemiskinan banyak dikaji oleh para ahli dari berbagai aspek dan dari berbagai disiplin ilmu dengan menggunakan bermacam-macam ukuran dan konsep. Para ekonom membahas kemiskinan dengan menggunakan istilah standar hidup, pendapatan, dan distribusi pendapatan. Para sosiolog mengkajinya dengan menggunakan istilah kelas, stratifikasi, dan marjinalitas. Sedangkan, para pemerhati masalah-masalah sosial lebih memperhatikan konsep tingkat hidup yakni melihat tingkat pendapatan, 
masalah pendidikan, kesehatan, perumahan, dan kondisi sosial masyarakat secara umum. Namun, sampai saat ini belum ada definisi yang baku tentang kemiskinan. Hal ini menunjukkan bahwa masalah kemiskinan itu sangat kompleks dan pemecahannya tidak mudah.

Al-Qur'an memandang bahwa kemiskinan adalah masalah sosial yang harus dientaskan. Bahkan penyakit berbahaya yang wajib diobati. Tulisan ini akan membahas model pengentasan kemiskinan dan pemberdayaan kaum fakir dan miskin yang ditawarkan Al-Qur'an untuk meningkatkan kesejahteraan mereka secara ekonomi. Sebelum menguraikan lebih jauh tentang bagaimana Al-Qur'an memberdayakan kaum fakir dan miskin terlebih dahulu perlu dijelaskan tentang konsep pemberdayaan. Selama ini ada dua strategi yang dilakukan dalam menanggulangi kemiskinan, yaitu rehabilitasi sosial dan pengembangan sosial (social develompment) atau pemberdayaan masyarakat (community empowerment).

Yang dimaksud pemberdayaan masyarakat (community empowerment) adalah "membantu klien (pihak yang diberdayakan), yakni kaum fakir dan miskin (dhuafa) agar mereka memperoleh daya dalam mengambil keputusan dan menentukan tindakan yang akan ia lakukan untuk perbaikan hidup mereka, termasuk mengurangi efek hambatan pribadi dan sosial melalui peningkatan.

Dalam konteks kajian ini, pengertian "pemberdayaan" meliputi segala usaha untuk membebaskan masyarakat miskin dari belenggu kemiskinan yang menghasilkan suatu situasi dimana kesempatan-kesempatan ekonomi tertutup bagi mereka. Karena kemiskinan yang terjadi tidak bersifat alamiah semata, melainkan hasil berbagai macam faktor yang menyangkut kekuasaan dan kebijakan, maka upaya pemberdayaan juga harus melibatkan kedua faktor tersebut. Salah satu indikator keberdayaan masayraakat adalah kemampuan dan kebebasan untuk membuat pilihan baik untuk menentukan atau memperbaiki kehidupannya.

Pearse dan Stiefel menyatakan bahwa proses pemberdayaan mengandung dua kecenderungan, primer dan sekunder. Kecenderungan primernya, proses pemberdayaan menekankan kepada proses memberikan atau mengalihkan sebagian kekuasaan, kekuatan atau kemampuan kepada masyarakat agar individu menjadi lebih berdaya. Sedangkan kecenderungan sekundernya melihat pemberdayaan sebagai proses menstimulasi, mendorong 
atau memotivasi individu agar mempunyai kemampuan atau keberdayaan untuk menentukan apa yang menjadi pilihannya. ${ }^{1}$

Konsep pemberdayaan merupakan hasil dari proses interaktif di tingkat ideologis dan praktis. Pada tingkat ideologis, merupakan hasil interaksi antara konsep top-down dan bottom-up antara growth strategy dan people centered strategy. Sedangkan di tingkat praktis, proses interaktif terjadi melalui pertarungan antar otonomi. Oleh karena itu konsep pemberdayaan mencakup pengertian pembangunan masyarakat (community development) dan pembangunan yang bertumpu pada masyarakat (community based development).

\section{Prinsip Pemberdayaan Fakir Miskin Menurut Al-Qur'an}

Kaum fakir dan miskin merupakan masalah sosial yang kompleks serta multidimensi. Menghadapi persoalan sosial yang akut ini, Al-Qur'an menawarkan beberapa prinsip dalam pemberdayaan kaum fakir dan miskin sebagai berikut:

Pertama, prinsip ta'äwūn, yakni prinsip kerjasama dan sinergi di antara berbagai pihak, yakni pemerintah, lembaga zakat, ulama, organisasi Islam dan berbagai kelompok masyarakat secara umum. Prinsip ini didasarkan pada firman Allah Swt sebagai berikut:

"Dan tolong-menolonglah kalian dalam (mengerjakan) kebaikan dan takwa, dan jangan tolong-menolong dalam berbuat dosa dan pelanggaran. Dan bertakwalah kalian kepada Allah, sesungguhnya Allah amat berat siksa-Nya." (QS. al-Mā’idah [5]:2)

Penanggulangan kemiskinan bukan monopoli pemerintah dengan berbagai departemen sektoralnya. Namun penanggulangan tersebut merupakan permasalahan multidimensi yang menjadi tanggungjawab seluruh pihak-pihak terkait. Dengan berbagai keterbatasan, baik aspek manajemen, organisasi maupun keuangan, pemerintah tidak akan mampu menjadi pemain tunggal. Penanggulangan kemiskinan harus dilaksanakan secara menyeluruh lintas sektoral dan regional, dengan melibatkan forum lintas pelaku. Karena itu kerjasama dan sinergi dalam pengentasan kemiskinan dan pemberdayaan kaum fakir dan miskin mutlak diperlukan. Bentuk tåāwūn ini meliputi kelembagaan,

${ }^{1}$ Ony S. Prijono dan A. M. W. Pranarka, Pemberdayaan Konsep, Kebijakan dan Implementasi, Jakarta: Center for Strategic and International Studies, 1996, h. 56-57

Volume VI/Edisi 1/Mei 2015 
manajemen, finansial, sumber daya manusia, program, metodologi, dan kebijakan sehingga melahirkan kekuatan terpadu dalam mengatasi kemiskinan.

Kedua, prinsip syūrā, yakni prinsip musyawarah di antara pemerintah dan pihak-pihak yang terkait dengan persoalan pemberdayaan kaum fakir dan miskin dalam satu program kepeduliaan terhadap masalah kemiskinan dengan mengidentifikasi masalah-masalah yang menyebabkan kemiskinan serta merumuskan langkah-langkah penanggulangan yang berkesinambungan.

Prinsip syūrā ini terutama terkait dengan cara-cara mengenali masalah dengan tepat, menemukan data yang akurat, melahirkan langkah yang cepat. Sebab penanggulangan kemiskinan tanpa social capital di atas akan rapuh jika dilakukan tanpa berpegang pada prinsip syūrā. Sebab prinsip syūrā ini berarti pengakuan dan penghargaan atas eksistensi pemikiran, ide, kehendak, pengalaman dari setiap komponen dalam komunitas. Dengan mekanisme syürā berarti memperluas tingkat keterlibatan dan partisipasi setiap komponen masyarakat dalam setiap tahapan pemberdayaan kaum fakir dan miskin.

\section{Model Pemberdayaan Fakir Miskin Menurut Al-Qur'an}

Al-Qur'an memandang bahwa kemiskinan adalah masalah sosial yang harus dientaskan. Bahkan penyakit berbahaya yang wajib diobati. Islam tidak mendukung teori perilaku individu yang memandang bahwa yang bertanggungjawab atas kemiskinan adalah orang miskin sendiri, bukan masyarakat, pemerintah atau orang kaya. Tetapi Islam juga tidak sependapat dengan teori struktural yang hanya memfokuskan pada penyebab struktural terhadap masalah kemiskinan. ${ }^{2}$

Di satu sisi, Islam mengakui dan melindungi kepemilikan individu yang sah. Setiap orang yang memperoleh harta secara sah, dia berkuasa penuh atas harta tersebut. Islam mengakui perbedaan dalam mendapatkan harta dan memandangnya sebagai sesuatu yang wajar sesuai dengan perbedaan keahlian dan kemampuan setiap orang serta sebagai pendorong seseorang agar bekerja dan berusaha secara sungguh-sungguh. Hanya saja perbedaan tersebut harus dalam konteks perbedaan yang terkendali dan berkeadilan. Perbedaan yang mendorong semangat kerja dan produktivitas, melahirkan keharmonisan dan saling melengkapi, bukan kontradiksi dan konflik.

2 Yusuf al-Qardhawi, Musykilat al-Faqr wa Kaifa 'Alajahā al-Islām, Beirut: Mu'assasah al-Risālah, 1985, hlm. 33-34 
Di sisi lain, Islam menuntut adanya distribusi kekayaan yang dapat menjamin standar kehidupan yang layak bagi setiap orang. Islam berpendapat bahwa problem ekonomi terletak pada praktik ketidakadilan manusia dalam distribusi kekayaan, bukan pada menipisnya kekayaan alam dibanding dengan kebutuhan manusia. ${ }^{3}$

Dari sini tampak bahwa persoalan bagaimana membebaskan kaum fakir dan miskin dari kemiskinan dan bagaimana memberdayakan kehidupan ekonomi mereka berkaitan erat dengan masalah pemanfaatan dan pendistribusian harta. Karena itu, upaya pembebasan dan pembedayaan fakir dan miskin terlebih dahulu harus melihat bagaimana ketentuan Al-Qur'an menyangkut pemanfaatan dan distribusi harta.

Dari ayat-ayat Al-Qur'an yang berbicara tentang harta (mäl, amwāl), ${ }^{4}$ secara garis besar dapat diambil dua ketentuan Al-Qur'an menyangkut pemanfaatan dan distribusi harta. Yang pertama berupa perintah dan anjuran dan yang kedua berupa larangan. Dari dua ketentuan ini, ada beberapa langkah yang ditempuh Al-Qur'an dalam mengentaskan kemiskinan dan memberdayakan kaum fakir dan miskin, yaitu perintah bekerja, perintah memberi makan, perintah berinfak, perintah mengeluarkan zakat, pembagian ganimah dan fa'i, penetapan hukum waris, larangan riba, larangan monopoli (ibtikēr) dan menimbun harta (iktināa)

\section{Perintah bekerja}

Kaum fakir dan miskin sebenarnya memiliki daya dan kemampuan untuk bangkit dari kemiskinannya. Mereka mampu mengatasi masalah sosial yang dihadapinya, akan tetapi mereka selama ini mereka belum menyadari tentang kemampuannya. Bekerja adalah senjata pertama dalam memerangi kemiskinan. Bekerja adalah penyebab utama penghasil harta/benda dan unsur utama pula dalam upaya memakmurkan diri dan bumi Allah. Dalam naungan sistem dan peraturan Islam, tidak ada seorang pekerja pun yang tidak mendapatkan upah dari hasil jerih payah dan keringatnya. Perintah bekerja ini terkait dengan kedudukan dan tujuan kehadiran manusia di bumi ini yang

\footnotetext{
${ }^{3}$ Abad Badruzaman, Teologi Kaum Tertindas (Kajian Tematik. Ayat-ayat Mustadb'afin dengan Pendekatan Keindonesiaan), Yogyakarta: Pustaka Pelajar, 2007, hlm. 137

${ }^{4}$ Kata mäl dengan berbagai derivasinya disebutkan dalam Al-Qur'an sebanyak 86 kali; 25 kali dalam bentuk tunggal (māl) dan 61 kali dalam bentuk plural (amwāi). Untuk lebih mengetahui bentukbentuk kata tersebut dan implikasi maknanya, lihat ibid, hlm. 139-144
} 
memiliki dua fungi, yaitu sebagai hamba Allah dan sebagai khalifah Allah. Sebagai hamba Allah (abdullah) manusia bertugas untuk mengabdi (beribadah kepada Allah) (QS. al-Dzariyat [51]:56). Mengabdi (beribadah) kepada Allah dapat dilakukan manusia melalui dua bentuk ibadah: ibadah khusus (ibadah mahdhah) dan ibadah umum (ibadah ghair mahdhah). Ibadah khusus adalah segala bentuk ibadah yang aturan dan tata caranya sudah ditentukan oleh Allah, seperti shalat, puasa, zakat dan haji. Sedangkan ibadah umum adalah segala bentuk amal saleh yang aturan dan tata caranya tidak ditentukan secara khusus oleh agama. Semua aktifitas dan kegiatan manusia dalam bidang apa pun, termasuk bekerja, sejatinya dilakukan dalam rangka pengabdian dan ibadah kepadaNya (QS. Al-An'am [6]:162).

Sebagai khalifah Allah di bumi (QS. al-Baqarah [2]:30) manusia menjadi wakil Allah dan kekuasaan-Nya untuk mengurus bumi dengan segala isinya dan memakmurkannya (QS. Hud [11]:61). Memakmurkan bumi artinya mensejahterakan kehidupan di dunia ini. Untuk itu, manusia wajib bekerja dan berusaha, beramal saleh (berbuat baik yang bermanfaat) bagi dirinya, masyarakat dan lingkungan hidupnya serta menjaga keseimbangan alam dan bumi yang dihuninya, sesuai dengan tuntunan yang diberikan Allah melalui agama.

Dorongan untuk bekerja itu semakin jelas ketika Allah menjadikan bumi dan segala isinya diperuntukkan dan ditundukkan Allah untuk kepentingan manusia (QS. Luqman [31]:20; Ibrāhīm [14]:32-33 dan al-Jātsiyah [45]:12). Dalam konteks ini, manusia dituntut untuk mempelajari hukumhukum alam dan mengolahnya secara serius dan penuh tanggung jawab dalam rangka pengembangan yang lebih baik serta menciptakan kesejahteraan dan kedamaian di alam semesta ini. Untuk menjalankan tugas kekhalifahan itu, manusia dibekali dengan berbagai potensi untuk mengubah kehidupan di dunia ke arah yang lebih baik (QS. al-Ra'd [13]:11), ditundukkan dan dimudahkan Allah baginya untuk mengelola dan memanfaatkan alam semesta (QS. al-Jaās|iyah [45]:12-13), ditetapkan arah yang harus ia tuju (QS. alDzāriyat [51]:56), dianugerahkan kepadanya petunjuk untuk menjadi pelita dalam perjalanan (QS. al-Baqarah [2]:38), dan ditetapkan tujuan hidupnya, yakni mengabdi kepada Ilahi (QS. al-Dzāriyat [51]:56).5 Dalam konteks

\footnotetext{
${ }^{5}$ M. Quraish Shihab, Membumikan Al-Qur'an, Bandung: Mizan, 1992, hlm. 69-70
} 
pemberdayaan kaum miskin, Al-Qur'an pun mendorong mereka agar mampu menolong dirinya sendiri, yaitu dengan mengubah pola pikir dan pola sikap, dengan menjadi manusia yang bertanggungjawab atas dirinya sendiri dengan bekerja keras dan berusaha mengubah keadaan dirinya.

\section{Perintah Memberi Makan}

Ayat-ayat Al-Qur'an yang membahas kemiskinan mendorong kaum Muslimin agar menjadi umat yang peduli dan berbagi dengan kaum dhuafa, termasuk kaum miskin, dengan memberi pertolongan pertama kepada mereka dalam bentuk perintah memberikan makanan pokok kepada orang miskin (tha'äm al-miskin) guna menjaga kelangsungan hidup mereka.

Dalam banyak ayat Al-Qur'an memberikan makanan pokok kepada orang miskin (tha'äm al-miskin) dihubungkan dengan kewajiban membayar fidyah. Secara bahasa, fidyah berarti "harta untuk tebusan" (al-Shaffāt [37]:107; (QS. al-Hadīd [57]:15). Sedangkan secara istilah, fidyah adalah "pengganti untuk membebaskan seorang mukallaf dari suatu larangan yang berlaku padanya". "Istilah fidyah sebenarnya tidak hanya terbatas pada masalah puasa seperti yang sering kita fahami, tapi juga digunakan pada haji. Bentuk fidyah juga beragam, tidak hanya memberi makanan pokok (tha'ám al-miskin) kepada orang miskin, tetapi tergantung kondisi dimana fidyah itu ada. Misalnya, fidyah terkait ibadah haji adalah puasa, bersedekah atau berkurban (QS. al-Baqarah [2]:196). Sementara fidyah dalam bentuk memberi makanan pokok kepada orang miskin terdapat dalam ayat berikut:

"Dan wajib bagi orang-orang yang berat menjalankannya (jika mereka tidak berpuasa) untuk membayar fidyah, (yaitu) memberi makanan pokok kepada seorang miskin. Barang siapa yang dengan kerelaan hati mengerjakan kebaikan, maka itulah yang lebih baik baginya. Dan berpuasa lebih baik bagi kalian jika kalian mengetahui." (QS. Al-Baqarah [2]:184)

Kewajiban fidyah dalam ayat di atas ditujukan kepada mereka yang tidak sanggup puasa dan tidak memiliki kemampuan untuk meng-qadha-nya di luar Ramadhan, seperti orang yang sudah lanjut usia (lansia), orang yang sakit berat yang menurut penilaian medis sudah tidak ada harapan sembuh lagi atau

6 'Ali bin Muhammad bin 'Ali al-Zain al-Syarīf al-Jurjāni, Kitāb at-Tà rî́ät, Beirut: Dār al-Kutub al'Ilmiyyah, cet ke-1, 1983, hlm.165

Volume VI/Edisi 1/Mei 2015 
wanita yang hamil dan menyusui. Yang terakhir ini diperdebatkan oleh para ulama apakah mereka wajib membayar fidyah atau meng-qadha-nya. ${ }^{7}$

Dalam QS. al-Hāqqah [69]:34, tha'äm al-miskin dihubungkan dengan keadaan dan nasib orang kafir di akhirat. Mereka adalah orang-orang yang menjadi kaya dan menjadi penguasa semata-mata karena kekuasaannya, bukan karena integritas moral dan kepribadiannya. Mereka -seperti halnya Firaunmenjadi penguasa yang suka menindas rakyatnya, arogan dan tidak peduli dengan nasib kaum miskin. Ketika di akhirat, Allah Swt menggambarkan keadaan mereka:

"Dan aku tidak mengetahui apa hisab terhadap diriku * Wahai kiranya kematian itulah yang menyelesaikan segala sesuatu * Hartaku sekali-kali tidak memberi manfaat kepadaku * Telah hilang kekuasaanku dariku * (Allah berfirman): Peganglah dia lalu belenggulah tangannya ke lehernya * Kemudian masukkanlah dia ke dalam api neraka yang menyala-nyala." (QS. al-H)āqqah [69]:26-32)

Mengapa mereka mengalami nasib buruk seperti itu? Ayat selanjutnya menjelaskan:

"Sesungguhnya dia dahulu (di dunia) tidak beriman kepada Allah Yang Maha Agung * Dan tidak mendorong (orang lain) untuk memberikan makanan kepada orang miskin * Maka tidak ada seorang teman pun baginya pada hari ini di sini * Dan tidak ada makanan sedikit pun kecuali dari darah dan nanah * Tidak ada yang memakannya kecuali orang-orang yang berdosa." (QS. al-H\} āqqah [69]:33-37)

Dalam ayat di atas terlihat bahwa memberi makan kepada orang miskin termasuk bagian dari pertolongan pertama dalam penanggulangan kemiskinan. Bahkan kewajiban bukan hanya tanggungjawab orang yang kaya, tetapi tanggungjawab semua orang, termasuk kelompok miskin sendiri. Hal itu

\footnotetext{
${ }^{7}$ Setidaknya ada tiga pendapat tentang persoalan ini. Pertama, mayoritas ulama mewajibkan qadha puasa, dengan alasan bahwa mereka seperti keadaan orang yang sakit dan seorang yang bepergian. Kedua, ulama yang berpendapat cukup dengan membayar fidyah. Ketiga, ulama yang berpendapat bahwa apabila wanita hamil/menyusui itu khawatir terhadap dirinya saja maka ia wajib qadha saja. Tetapi apabila mereka khawatir terhadap janinnya maka ia wajib qadha dan fidyah. Dr. Yusuf alQardhawi mempunyai pendapat, bahwa cukup untuk membayar fidyah bagi wanita yang tidak hentihentinya hamil dan menyusui. Tahun ini hamil, tahun berikutnya menyusui, kemudian hamil dan menyusui, dan seterusnya, sehingga ia tidak mendapatkan kesempatan untuk mengqadha puasanya. Sedangkan bagi yang kehamilan/menyusuinya tidak terus menerus dan mempunyai kesempatan mengqadha puasa di luar Ramadhan, sebaiknya ia mengqadhanya.
} 
terlihat dalam penggunaan kata yahudhdhu (menganjurkan) yang mengisyaratkan bahwa mereka yang tidak memiliki kelebihan apa pun, tetap dituntut, minimal berperan sebagai penganjur pemberi makanan. Dengan kata lain, kalau tidak mampu secara langsung, minimal kita menganjurkan orang-orang yang mampu untuk memperhatikan nasib mereka. Peran ini sebenarnya bisa dilakukan oleh siapa pun. Jadi, Al-Qur'an mengundang setiap orang untuk ikut merasakan penderitaan dan kebutuhan orang lain, walaupun dia sendiri tidak mampu mengulurkan bantuan materiil kepada mereka. Singkatnya, Al-Qur'an menyuruh setiap orang untuk berpartisipasi dalam pengentasan kemiskinan atau dan pemberdayaan kaum miskin (kaum lemah).

Di sisi lain, dalam banyak ayat Al-Qur'an menggunakan redaksi tha'äm al-miskin (QS. al-Baqarah [2]:184; al-Mā'idah [5]:95; QS. al-Hāqqah [69]:34; alFajr [89]:18; al-Mā'ūn [107]:3) yang secara harfiah berarti "makanan orang miskin", bukan ith"äm al-miskinn yang berarti "memberi makan orang miskin". Redaksi ini menyiratkan bahwa setiap orang yang menganjurkan dan atau memberi makan kepada orang miskin, tidak merasa bahwa apa yang diberikannya adakah miliknya sebagai sebuah kebaikan darinya, tetapi makanan yang diberikan itu pada hakikatnya adalah makanan milik/hak orang miskin yang ada padanya atau yang Allah Swt titipkan melalui dirinya.

Begitu pentingnya menganjurkan dan memberikan makanan kepada orang miskin, sampai Allah Swt dalam QS. al-Fajr dan al-Mā ūn mengecam mereka yang tidak melakukannya. Dalam QS. al-Mā‘ūn, Allah menyebut mereka -bersama orang yang menghardik anak yatim- sebagai orang yang mendustakan al-din (dalam pengertian agama), yakni jalan hidup yang benar, cara ibadah yang benar atau cara perilaku yang benar; atau mendustakan al-din (dalam pengertian pembalasan (hari akhir). Karena mereka yang enggan membantu anak yatim/miskin dengan alasan bahwa bantuannya kepada mereka tidak akan menghasilkan apa-apa, pada hakikatnya mereka tidak percaya akan adanya hari pembalasan (hari akhir). Karena mereka yang meyakininya percaya, bahwa kalau pun bantuan yang diberikannya di dunia tidak menghasilkan sesuatu di dunia, pasti balasannya akan diperoleh di akhirat.

\footnotetext{
${ }^{8}$ Istilah ith'äm al-miskìn digunakan dalam QS. al-Mā’idah [5]:89 dan al-Mujādilah [58]:4
} 
Dalam QS. al-Fajr Allah memperingatkan tentang siksa kepada para pendurhaka di masa lalu dan memperingatkan tentang pengawasan Allah, kemudian menjelaskan tentang ujian dan pengaruhnya atas pahala dan siksa Allah. Dalam surah ini dgambarkan orang durhaka yang diuji oleh Allah dengan berbagai kenikmatan dunia, seperti harta, kedudukan, kekuatan dan sebagainya, ia menjadi sombong dan takabur. Dengan bangga tanpa menyadari nikmat itu sebagai ujian, ia berkata "Tuhanku telah memuliakanku karena memang aku wajar dimuliakannya, sebab Dia mencintaiku”. Mereka menduga bahwa kenikmatan yang mereka peroleh adalah pertanda kemuliaan mereka di sisi Allah. Sebaliknya, jika Allah mengujinya dengan sesuatu yang tidak menyenangkan, seperti kesulitan ekonomi, penyakit, kegagalan dan berbagai penderitaan lain, ia berkata dengan kesal dan menggerutu, "Tuhanku telah menghinakanku". Ucapan ini merupakan prasangka buruk kepada Allah Swt dan ekspresi keputusasaan (QS. al-Fajr [89]:15-16).

Kemudian dalam ayat-ayat selanjutnya (ayat 17-20), Allah Swt membantah anggapan mereka itu dan menegaskan bahwa kemuliaan berpangkal dari kebaikan dan ketaatan, sementara kehinaan disebabkan kedurhakaan kepada Allah. Dalam rangkaian ayat itu disebutkan empat amal yang menjauhkan seseorang dari Allah, yakni: (1) Tidak memuliakan anak yatim, (2) Tidak menganjurkan untuk memberi makan kepada orang miskin, (3) Memakan warisan (harta pusaka) dengan cara menghimpun, (4) Mencintai harta secara berlebihan. Sementara itu, dalam QS. al-Muddatstsir [74]:40-47, Allah Swt menyebutkan empat hal yang menyebabkan mereka masuk neraka Saqar, diantaranya tidak memberi makan kepada orang miskin.

Selain terkait dengan kewajiban membayar fidyah, memberi makan juga terkait dengan kafarah, seperti kafarah melanggar sumpah, kafarah pelanggaran atas salahsatu kewajiban haji, kafarah zihar dan lain-lain (QS. Al-Mā’idah [5]:89, 95; al-Mujādilah [58]:4). Di tempat lain, Al-Qur'an menyebutkan bahwa memberi makan kepada orang miskin sebaiknya berupa makanan yang terbaik yang mereka sukai (QS. al-Insān [76]:8).

Perintah memberi makanan kepada orang miskin (tha'äm al-miskin) dalam dengan bentuk fidyah atau kafarah, selain sebagai bentuk pertolongan pertama kepada mereka guna menjaga kelangsungan hidup mereka, juga dapat dipahami sebagai cara Islam dalam mengentaskan kemiskinan dan memberdayakan kaum miskin. 


\section{Perintah berinfak}

Kata infak (infäq) adalah bentuk masdar dari kata anfaqa yunfiqu. Sedangkan kata anfaqa berasal dari nafaqa yang artinya "berlalu dan habis" (madhā wa nafadza). ${ }^{9}$ Tetapi ketika kata itu digandengkan dengan kata al-mäl (infäq al-mā̄) maka artinya menjadi sharrafahu (membelanjakan atau mendayagunakannya). ${ }^{10}$ Sedangkan jika harta itu dihabiskan tidak dalam rangka pendayagunaan, melainkan secara sia-sia, maka tindakan tersebut disebut pemborosan atau penghambur-hamburan (tabdzìr al-māl). Bedanya, yang pertama (infāq al-māl) dianjurkan dan yang kedua (tabdzir al-mäl) dilarang. ${ }^{11}$

Perintah berinfak (membelanjakan harta) menjadi fungsi dan tujuan utama kepemilikan harta atau modal. Allah Swt sangat mencintai hambahamba-Nya yang mensyukuri nikmat harta dengan berinfak (investasi, produksi, konsumsi, donasi). Maka ditemukan banyak ayat Al-Qur'an maupun hadis Nabi Saw yang mendorong kaum Muslimin untuk berinvestasi, untuk konsumsi memenuhi kebutuhannya, maupun anjuran untuk bersedekah. Karena baik investasi, konsumsi, maupun donasi, merupakan sarana untuk memutar harta, agar tidak bergulir di kalangan tertentu (QS. al-Hasyr [59]:7). Baik langsung atau tidak langsung perputaran harta melalui konsumsi, investasi bahkan donasi akan berpengaruh positif bagi perekonomian masyarakat.

Nilai suatu harta dalam Islam tak semata ditentukan oleh banyaknya (kuantitas) harta itu atau return yang diterima, melainkan juga oleh manfaat yang dimiliki oleh harta itu, baik manfaat bagi pemilik maupun orang lain. Karena itu, baik konsumsi, maupun donasi -yang secara lahir mengurangi harta- sebenarnya menambah harta dan menjadikannya menjadi sesuatu yang bernilai.

Terdapat perbedaan pandangan kapitalisme dengan Islam dalam persoalan ini. Bagi kapitalisme, menyumbangkan harta akan menyebabkan kemiskinan, karena mengurangi jumlah harta. Sementara Islam menganggap bahwa infak (sedekah) akan memberikan manfaat materi (penambahan dan pelipatgandaan harta) dan manfaat maknawi (ampunan, ketenangan,

\footnotetext{
${ }^{9}$ al-Rāgib al-Isfahāni, Mufradāt fì Garīb al-Qurān, Beirūt: Dār al-Ma'rifah, t.th, hlm. 523

10 Jamāl al-Dīn Ibn Manzhūr al-Anshārī, Lisān al-'Arab, Beirut: Dār Shādir, cet ke-3, 1414 H, juz 10, hlm. 357-358

11 Diantara ayat-ayat yang melarang pemborosan adalah QS. al-Isrā’ [17:26-27, al-An`ām [6]:141, al-Furqān [25]:67
} 
keberkahan) bagi pelakunya, sebagaimana dijanjikan Allah Swt dalam banyak ayat Al-Qur'an (QS. al-Baqarah [2]:268; Saba' [34]:39; Fātir [35]:29-30)

Pada dasarnya dengan harta yang dimilikinya seseorang bebas membelanjakannya. Ia bebas berinvestasi, bebas berproduksi, bebas mengkonsumsi, atau mendonasikan kepada orang lain. Kebebasan berinfak ini menjadi prinsip dalam ekonomi Islam. Akan tetapi kebebasan yang dimaksud bukanlah kebebasan mutlak tanpa nilai. Melainkan kebebasan yang terbingkai oleh kaidah dan aturan, sehingga dapat dipertanggungjawabkan secara moral kepada Allah Swt dan juga sosial. Tiga aspek ekonomi Islam yang meliputi ilähiyah (ketuhanan), ta'ámuliyah akblaqiyah (moralitas dalam hubungan dengan sesama) dan bìah (lingkungan) menjadi nilai-nilai yang membingkai kebebasan itu. ${ }^{12}$

Perintah Al-Qur'an untuk menginfakkan sebagian harta yang diberikan Allah adalah salah satu upaya Al-Qur'an dalam mengentaskan kemiskinan dan memberdayakan kaum fakir dan miskin. Dari ayat-ayat Al-Qur'an yang berbicara tentang infak, kita dapat mengkategorikannya sebagai berikut:

a. Perintah dan larangan

"Dan infakkan (harta bendamu) di jalan Allah, dan janganlah kalian menjatuhkan dirimu sendiri ke dalam kebinasaan, dan berbuat baiklah, karena sesungguhnya Allah menyukai orang-orang yang berbuat baik." (QS. al-Baqarah [2]:195)

"Hai orang-orang yang beriman, nafkahkanlah (di jalan Allah) sebagian dari hasil usahamu yang baik-baik dan sebagian dari apa yang Kami keluarkan dari bumi untuk kamu. Dan janganlah kamu memilih yang buruk-buruk lalu kamu nafkahkan daripadanya, padahal kamu sendiri tidak mau mengambilnya melainkan dengan memicingkan mata terhadapnya. Dan ketahuilah, bahwa Allah Maha Kaya lagi Maha Terpuji.” (QS. alBaqarah [2]:267)

"Dan infakkanlah sebagian dari apa yang telah Kami berikan kepadamu sebelum datang kematian kepada salah seorang di antara kalian; lalu ia berkata: "Tuhanku, mengapa Engkau tidak menangguhkan (kematian) ku sampai waktu yang dekat, sehingga aku dapat bersedekah dan aku termasuk orang-orang yang saleh?” (QS. al-Munāfiqūn [63]:10)

${ }^{12}$ Husein Ghanim, al-Iqtishād al-Islāmi: Thabīatubu wa Majālatuhu, Kairo: Dār al Wafā’, Cet. Ke-I, 1411-1991, hlm. 30-36. 
Ayat yang terakhir selain memerintahkan untuk berinfak dari sebagian harta yang Allah berikan, juga merupakan peringatan agar seseorang berinfak sebelum datang kematian dan hari akhir dimana ketika itu seseorang tidak dapat lagi berinfak dan beramal saleh untuk menyelamatkan dirinya.

b. Janji dan pahala

"Perumpamaan orang-orang yang meninfakkan hartanya di jalan Allah adalah seperti sebutir benih yang menumbuhkan tujuh bulir, pada setiap bulir terdapat seratus biji. Allah melipat gandakan (pahala) bagi siapa yang Dia kehendaki, dan Allah Maha Luas (kurnia-Nya) lagi Maha Mengetahui * Orang-orang yang meninfakkan hartanya di jalan Allah, kemudian mereka tidak mengiringi apa yang diinfakkan itu dengan menyebut-nyebut pemberiannya dan dengan tidak menyakiti (perasaan si penerima), bagi mereka pahala di sisi Tuhan mereka, tidak ada kekhawatiran terhadap mereka dan tidak (pula) mereka bersedih hati." (QS. al-Baqarah [2]:261262)

"Dan perumpamaan orang-orang yang menginfakkan hartanya karena mencari keridhaan Allah dan untuk keteguhan jiwa mereka, seperti sebuah kebun yang terletak di dataran tinggi yang disiram oleh hujan lebat, maka kebun itu menghasilkan buahnya dua kali lipat. Jika hujan lebat tidak menyiraminya, maka hujan gerimis (pun memadai). Dan Allah Maha Melihat apa yang kalian kerjakan." (QS. al-Baqarah [2]:265)

"Bukanlah kewajibanmu menjadikan mereka mendapat petunjuk, akan tetapi Allah-lah yang memberi petunjuk kepada siapa yang dikehendakiNya. Dan kebaikan apa saja yang kalian infakkan maka (pahalanya) itu untuk kalian sendiri. Dan janganlah kalian menginfakkan kecuali karena mencari keridhaan Allah. Dan kebaikan apa saja yang kalian inffakkan, maka (pahalanya) akan disempurnakan buat kalian dan kalian tidak akan dizalimi (dirugikan).” (QS. al-Baqarah [2]:272)

Selain kata infak secara langsung, Al-Qur'an juga menyebut infak dengan istilah qardh al-hasan (pinjaman yang baik), dimana pahalanya adalah pelipatgandaan pahala dengan banyak, penghapusan dosa, dan dimasukkan ke surga nanti di akhirat (al-Baqarah [2]:245; al-Hadīd [57]:11, 18, al-Muzzammil [73]:20; al-Mā'idah [5]:12 dan al-Taghābun [64]:17 
c. Ancaman keras

"Hai orang-orang yang beriman, sesungguhnya sebagian besar dari orangorang alim Yahudi dan rahib-rahib Nasrani benar-benar memakan harta orang dengan jalan yang batil dan mereka menghalang-halangi (manusia) dari jalan Allah. Dan orang-orang yang menyimpan emas dan perak dan tidak menafkahkannya pada jalan Allah, maka gembirankanlah mereka dengan siksa yang pedih * Pada hari dipanaskan emas perak itu dalam neraka Jahannam, lalu dibakar dengannya dahi mereka, lambung dan punggung mereka (lalu dikatakan) kepada mereka: Inilah harta bendamu yang kalian simpan untuk dirimu sendiri, maka rasakanlah sekarang (akibat dari) apa yang kalian simpan itu". (QS. al-Taubah [9]:34-35)

Dalam ayat ini Allah mengancam mereka yang tidak menafkahkan hartanya (seperti emas dan perak) dengan ancaman siksa yang keras di akhirat, yaitu harta benda yang mereka simpan dan tidak dikeluarkan nafkahnya akan dipanaskan di dalam nereka untuk kemudian dijadikan sebagai alat penyiksaan bagi mereka.

d. Penjelasan apa yang harus diinfakkan

"Dan mereka bertanya kepadamu apa yang mereka infakkan. Katakanlah: "Yang lebih dari keperluan." Demikianlah Allah menerangkan ayat-ayatNya kepadamu supaya kalian berfikir". (QS. al-Baqarah [2]:219)

Ayat ini menegaskan bahwa infak diberikan dari harta yang melebihi kebutuhan pokok.

e. Penjelasan tentang kepada siapa berinfak

"Mereka bertanya kepadamu tentang apa yang mereka infakkan. Katakanlah, “Apa saja harta yang kalian infakkan maka (berikanlah) kepada kedua orang tua, kaum kerabat, anak-anak yatim, orang-orang miskin dan orang-orang yang sedang dalam perjalanan." Dan kebaikan apa saja yang kalian lakukan maka sesungguhnya Allah Maha Mengetahuinya." (QS. al-Baqarah [2]:215)

Ayat ini selain memberi penjelasan tentang kepada siapa saja infak kita salurkan, juga memberi tuntunan tentang skala prioritas dalam berinfak, yakni al-aqrab fa al-aqrab tsumma al-äkharün, yakni pertama-tama kepada pihak yang memiliki hubungan paling dekat dalam kekerabatan, kemudian yang dekat, agak jauh, jauh dan seterusnya. Hal ini dipertegas dengan sabda Nabi Saw: 
"Jabir berkata: Ada seseorang dari Bani 'Uz|rah yang membebaskan budak miliknya setelah dia meninggal. Hal itu sampai kepada Rasulullah Saw, lalu beliau bersabda, "Apakah kamu memiliki harta selain itu?" Dia menjawab, "Tidak." Lalu beliau bertanya, "Siapa yang mau membelinya dariku?" Lalu Nu aim bin Abdullah al- 'Adawi membelinya dengan harga delapan ratus dirham. Lalu ia membawa (uang itu) kepada Rasulullah Saw dan menyerahkannya kepada beliau, lalu beliau bersabda, "Mulailah dengan dirimu dan bersedekahlah kepada dirimu. Jika memiliki kelebihan, maka bersedekahlah kepada keluargamu. Jika masih memiliki kelebihan, maka bersedekahlah kepada kerabatmu. Jika masih memiliki kelebihan, maka baru ini dan itu." Maksud beliau, kepada orang (lain) yang ada di hadapanmu, di samping kanan dan kirimu." (HR. Muslim). ${ }^{13}$

Secara keseluruhan, pesan yang disampaikan oleh ayat-ayat infak adalah keharusan adanya kepedulian dan keberpihakan kepada kelompok-kelompok miskin. Bahkan "jalan Allah" yang disebut beberapa ayat (misalnya QS. alBaqarah [2]:195, 261, 262, 354, al-Taubah [9]:34 dan al-Hadīd [57]:10) sebagai sasaran infak pun, dalam konteks sekarang bisa dimaknai sebagai semua kegiatan sosial, termasuk di dalamnya program pengentasan kemiskinan dan pemberdayaan orang miskin. ${ }^{14}$

\section{Perintah mengeluarkan zakat}

Zakat adalah salah satu ibadah pokok dalam Islam yang menjadi kewajiban bagi setiap individu (mukallaf) yang memiliki harta untuk mengeluarkan harta tersebut sesuai dengan aturan-aturan yang berlaku dalam zakat itu sendiri. Dalam Al-Qur'an, kata zakat dan derivasinya disebut 30 kali, dan 27 diantaranya digandengkan dengan kewajiban shalat. Ini menunjukkan bahwa kedudukan zakat dalam Islam sangat penting seperti halnya shalat. Karena itu, zakat termasuk rukun Islam dan orang yang menentangnya dianggap kafir.

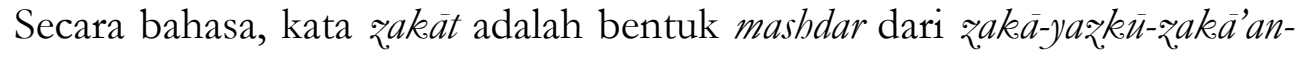
zakātan yang memiliki beberapa pengertian, yakni al-barakah (keberkahan), alnamä' (pertumbuhan/perkembangan), al-thahärah (kesucian) dan al-shalāh

\footnotetext{
${ }^{13}$ Muslim, "Shahīh Muslim", hadis no. 1663, Program Hadis Mausū'at al-Hadìts al-Syarif, edisi 6.2, Harf Information Technology Company, 1998-2000

14 Badruzzaman, Teologi..., hlm. 205
} 
(keberesan). Sedangkan secara istilah, zakat adalah sejumlah harta dengan yang telah memenuhi persyaratan tertentu yang diwajibkan Allah Swt untuk diberikan kepada yang berhak menerimanya.

Selain istilah zakat, Al-Qur'an dan hadis Nabi Saw juga menggunakan istilah infak (QS. al-Taubah [9]:34), sedekah (QS. at-Taubah [9]:60, 103) dan hak (QS. al-An'ām [6]:141) untuk memaknai zakat. Hal ini berbeda dengan pemahaman kita yang memahami zakat sebagai harta yang wajib dikeluarkan, sedangkan infak dan sedekah adalah sifatnya anjuran bukan kewajiban. ${ }^{15}$ Dipergunakannya kata-kata tersebut dengan maksud zakat, karena memiliki kaitan yang sangat kuat dengan zakat. Zakat disebut infak karena hakikatnya zakat itu adalah penyerahan harta untuk kebajikan-kebajikan yang diperintahkan Allah Swt. Zakat disebut sedekah karena memang salah satu tujuan utama zakat adalah untuk mendekatkan diri (taqarrub) kepada Allah Swt dan juga bukti kebenaran keimanan (shadaqa) seseorang kepada Allah Swt dan kepada ajaran-Nya. Zakat disebut hak karena zakat itu merupakan ketetapan yang bersifat pasti dari Allah Swt yang harus diberikan kepada mereka yang berhak menerimanya (mustahik). ${ }^{16}$

Zakat selain memiliki dimensi ritual dalam rangka melaksanakan perintah Allah Swt, juga terkait dengan dimensi moral-psikologis, yakni zakat diharapkan dapat mengikis habis ketamakan dan keserakahan si kaya yang memiliki kecenderungan cinta harta. Zakat juga terkait dengan dimensi sosial, yakni zakat dikonsepsikan dapat menghapus taraf kemiskinan masyarakat. Dan zakat juga terkait dengan dimensi ekonomi, yakni difungsikan untuk mencegah penumpukan harta pada sebagian kecil orang dan mempersempit kesenjangan ekonomi dalam masyarakat (QS. al-Hasyr [59]:7)

Di antara berbagai sarana pengentasan kemiskinan, zakat merupakan salah satu potensi terbaik upaya pengentasan kemiskinan dan pemberdayaan mereka. Zakat bukanlah amal baik individual atau sumbangan sukarela. Zakat

15 Kata infak (infäq) berasal dari anfaqa yunfiqu yang artinya "membelanjakan atau membiayai". Makna infak menjadi khusus tatkala dikaitkan dengan upaya realisasi perintah-perintah Allah. Infak hanya berkaitan dengan materi saja. Hukum infak ada yang wajib, seperti zakat dan nadzar, ada yang sunnah, mubah bahkan ada yang haram. Sedangkan sedekah (shadaqah) berasal dari kata shadaqa yang artinya "benar". Sedekah adalah sebuah tindakan yang bisa menjadi bukti akan kebenaran iman seseorang. Jika infāk hanya berkaitan dengan materi, maka sedekah bisa berupa materi atau non materi. Hukum sedekah ada yang wajib seperti zakat, dan ada juga yang sunnah.

${ }^{16}$ Didin Hafidhuddin, dkk, Fiqh Zakat Indonesia, Jakarta: BAZNAS, cet ke-1, 2013, hlm. 14 
merupakan hak dan kewajiban. Zakat adalah sebuah sistem yang diciptakan Allah untuk hambanya dalam upaya memberikan jaminan sosial masyarakat.

Terkait dengan pemberdayaan zakat sebagai instrumen pengentasan kemiskinan dan pemberdayaan kaum miskin, maka keberadaan para pengurus zakat ('ämilīn) menjadi sangat penting dan strategis. Karena itu, zakat adalah satu-satunya ibadah dalam Islam yang disebut dalam Al-Qur'an ada "petugasnya", yakni amil sebagaimana terbaca dalam QS. al-Taubah [9]:60.

Al-Qurthubī menafsirkan kata 'ámilìn sebagai orang-orang yang ditugaskan (oleh imam/pemerintah) untuk mengambil, menuliskan, menghitung dana zakat yang diambil dari muzakki untuk kemudian diberikan kepada golongan yang berhak menerimanya. Hal ini dipertegas lagi dengan adanya perintah (mandat) yang diberikan kepada penguasa untuk memungut zakat dari harta orang-orang yang wajib zakat (QS. al-Taubah [9]:103). Keberadaan 'ámilin ini didukung oleh fakta historis bahwa Rasulullah Saw pernah mengutus Ibnu Lutaibah untuk mengurus zakat Bani Sulaim, juga mengutus Mu'adz bin Jabal untuk memungut zakat dari penduduk Yaman.

Secara tersirat, Al-Qur'an ingin menunjukkan bahwa keberadaan amil dalam mengelola zakat memiliki peran yang sangat strategis. Artinya, amil diharapkan mampu mewujudkan cita-cita zakat sebagai salah satu instrumen dalam sistem ekonomi Islam dalam rangka menciptakan pemerataan ekonomi dan harmonisasi antar umat. Dalam konteks ini, para amil zakat tidak hanya sekedar mengumpulkan dan mendistribusikan zakat, tetapi juga dituntut untuk mampu menciptakan pemerataan ekonomi umat sehingga kekayaan tidak hanya berputar pada satu golongan atau satu kelompok orang saja (QS. alHasyr [59]:7)

Penegasan amil dalam konteks zakat di dalam Al-Qur'an diungkapkan dalam bentuk plural ('ämilīn). Artinya, 'ämilīn itu bukan orang per orang yang bekerja sendiri-sendiri, tanpa keterkaitan satu sama lain. Tetapi 'ámilin harus dilihat dan dipahami sebagai kumpulan orang dan kolektifitas yang memiliki legalitas, terikat dalam institusi dan sistem, serta wajib menyampaikan pertanggungjawaban atas pelaksanaan tugasnya kepada pemerintah dan masyarakat. ${ }^{17}$

\footnotetext{
${ }^{17}$ Ibid, hlm. 4-5
} 
Para amil harus mampu memilih dan memilah agar penyaluran zakat tepat sasaran dan jangan sampai diberikan kepada orang yang tidak berhak, Allah swt memperingatkan bahwa ada orang yang tidak pantas menerima zakat tetapi ingin mendapatkan bagiannya lalu orang tersebut mencela Nabi Muhammad Saw mengenai masalah pembagian harta zakat (QS. al-Taubah [9]:58).

Amil zakat harus mampu menciptakan dan merumuskan strategi pemanfaatan zakat yang berdaya guna dan berhasil guna. Amil zakat juga harus mampu mengeksplorasi berbagai potensi umat sehingga dapat diberdayakan secara optimal. Dengan demikian, zakat menjadi lebih produktif dan tidak hanya sekedar memiliki fungsi karitatif.

Secara lebih jelas, Yusuf Al-Qardhawi menyebutkan urgensi keberadaan amil, yaitu: pertama, jaminan terlaksananya syariat zakat (bukankah ada saja manusia-manusia yang berusaha menghindar bila tidak diawasi oleh penguasa?). Kedua, pemerataan (karena dengan keterlibatan satu tangan, diharapkan seseorang tidak akan memperoleh dua kali dari dua sumber, dan diharapkan pula semua mustahiq akan memperoleh bagiannya). Ketiga, memelihara harga diri para mustahik, karena mereka tidak perlu berhadapan langsung dengan para muzakki, dan mereka tidak harus pula datang meminta. Keempat, sektor (ashnaf yang harus menerima) zakat, tidak terbatas pada individu, tetapi juga untuk kemaslahatan umum, dan sektor ini hanya dapat ditangani oleh pemerintah. ${ }^{18}$

Di Indonesia, untuk mewujudkan fungsi zakat untuk kesejahteraan dan pengentasan kemiskinan, maka penguatan institusi amil menjadi bagian tak terpisahkan dari penguatan sistem zakat nasional. Langkah ke arah itu terus dilakukan sebagai implementasi Undang-undang Republik Indonesia Nomor 23 Tahun 2011 tentang Pengelolaan Zakat. Dalam Undang-undang tersebut digariskan, bahwa pengelolaan zakat bertujuan: Pertama, meningkatkan efektivitas dan efisiensi pelayanan dalam pengelolaan zakat. Kedua, meningkatkan manfaat zakat untuk mewujudkan kesejahteraan masyarakat dan penanggulangan kemiskinan. ${ }^{19}$

Secara empiris, berbagai riset telah membuktikan peran zakat terhadap pengentasan kemiskinan dan pemberdayaan kaum miskin. Tahun 2010,

\footnotetext{
${ }^{18}$ Ibid, hlm. 4-5

${ }^{19}$ Undang-undang Republik Indonesia Nomor 23 Tahun 2011 tentang Pengelolaan Zakat
} 
misalnya, IMZ melakukan riset tentang peran zakat dalam pengentasan kemiskinan. Hasilnya adalah dari sebanyak 8 lembaga zakat yang dilakukan survey terhadap program-program pemberdayaan masyarakatnya, menunjukkan bahwa zakat mampu mengangkat kelompok miskin sebesar $10,79 \%$. Tren kemampuan zakat mengurangi kemiskinan yang dialami sebagian masyarakat Indonesia semakin mengalami peningkatan. Informasi yang direlease IMZ bulan Agustus 2011 lalu ternyata peran zakat dalam pengentasan kemiskinan angkanya meningkat menjadi $24 \%$ lebih. ${ }^{20}$

Irfan Syauqi Beik dalam studinya terhadap 1.195 rumah tangga mustahik penerima zakat di wilayah Jabodetabek, menyimpulkan bahwa zakat mampu menaikkan pendapatan rumah tangga mustahik sebesar 8,94\%. Daya beli rumah tangga mustahik juga mengalami kenaikan sebesar 1,90\%. Meski angka tersebut masih kecil, akibat penghimpunan zakat yang juga masih kecil, namun tren yang ditunjukkan sangat positif. ${ }^{21}$ Sedangkan Mintarti et al, setelah melakukan studi terhadap 1.693 rumah tangga mustahik di lima provinsi, menunjukkan bahwa jumlah kemiskinan mustahik dapat dikurangi sebesar $21,11 \%$, naik dibandingkan kinerja sebelumnya, yaitu 16,97\%. Demikian pula dengan tingkat kedalaman dan keparahan kemiskinan mustahik yang juga diminimalisir. Selanjutnya, dari sisi time taken to exit poverty, keberadaan program zakat mampu mempercepat upaya pengentasan kemiskinan mustahik, dari 7 tahun menjadi 5,1 tahun sebagaimana terlihat pada gambar berikut ini:22

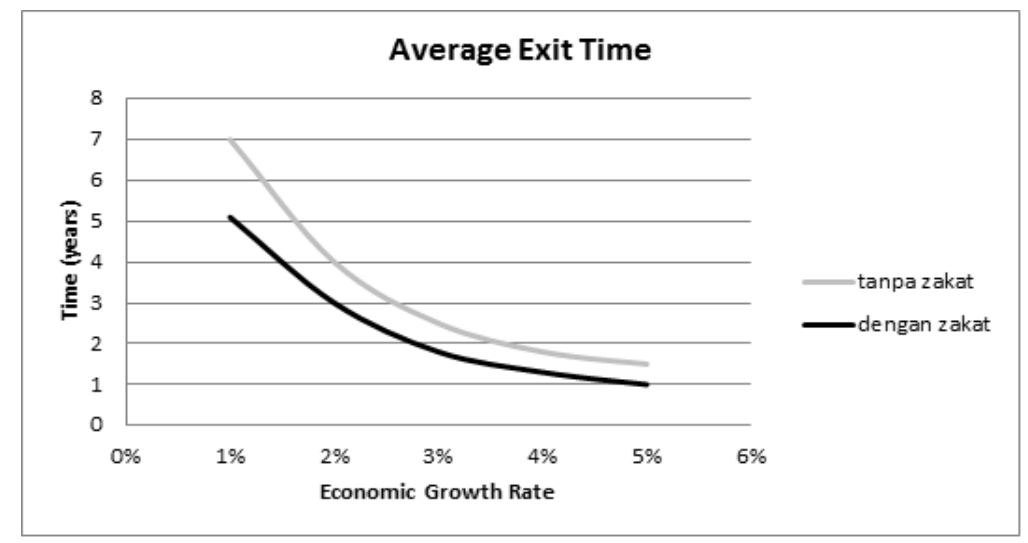

20 http://www.imz.or.id/new/article/1131/zakat-masyarakat-dan-negara-dalam-pengentasankemiskinan-2/, diakses 6 Oktober 2014

${ }^{21}$ Irfan Syauqi Beik, Economic Role of Zakat in Reducing Poverty and Income Inequality: A Case Study in the Province of DKI Jakarta, Indonesia, Jerman: La,bert Academic Publishing, 2013

${ }^{22}$ Mintarti, et al, Indonesia Zakat and Development Report, Jakarta: IMZ, 2012 


\section{Pemberian Sebagian Warisan}

Ketika warisan akan dibagikan Al-Qur'an memerintahkan kepada ahli waris, sebelum harta itu dibagikan, agar mereka memberikan sebagiannya kepada kerabat, anak yatim dan orang miskin.

"Dan apabila sewaktu pembagian (warisan) itu hadir kerabat, anak yatim dan orang miskin, maka berilah mereka dari harta itu (sekedarnya) dan ucapkanlah kepada mereka perkataan yang baik”. (QS. al-Nisā’ [4]:8)

Dalam ayat itu Allah menyebut salahsatu kelompok yang perlu diperhatikan dan mendapat pembagian dari harta warisan sebelum dibagikan kepada ahli waris, selain kerabat (yang bukan ahli waris) dan anak yatim, adalah orang miskin. Pemberian ini dapat dipahami sebagai cara Islam mengentaskan kemiskinan dan memberdayakan mereka dari kemiskinan.

\section{Pembagian Ganimah dan Fa'i}

Ganimah secara etimologi berarti "apa yang diperoleh seseorang atau sekelompok orang melalui usaha." 23 Ibnu Manẓūr dengan mengutip pendapat al-Azhari mengartikannya dengan "apa yang diperoleh kaum Muslim dari harta kaum musyrik dengan mengerahkan kuda dan unta (perang)." 24 Karena itu, dalam terminologi fikih ganimah umumnya diartikan rampasan perang, yakni harta yang diperoleh dari musuh Islam melalui peperangan dan pertempuran yang pembagiannya diatur oleh agama. Ganimah meliputi harta yang dapat dibawa dari perang, tawanan, dan tanah. Istilah-istilah yang berkaitan dengan ganimah adalah nafal (jamaknya anfāl) yang berarti tambahan, salab yang berarti rampasan.

As-Sayyid Sābiq mengidentikkan ganimah dengan nafal. Sementara, menurut Wahbah Al- Zuhaili, keduanya berbeda. Menurutnya, nafal adalah harta rampasan perang yang diberikan oleh imam secara khusus untuk tentara tertentu sebagai dorongan kepadanya agar aktif bertempur. Dinamakan demikian karena ia merupakan tambahan hak seseorang atas rampasan perang, lebih dari hak (saham) yang dimilikinya dalam pembagian harta ganimah. Salab adalah perlengkapan perang (termasuk kuda atau unta yang ditunggangi) yang berhasil dirampas tentara Islam dari prajurit musuh yang dibunuhnya.

${ }^{23}$ Syams al-Dīn al-Qurthubi, al-Jāmi' li Abkeàm al-Qur'ān, tahqīq Ahmad al-Bardūnī wa Ibrāhīm Atfīsy, Kairo: Dār al-Kutub al-Mishriyyah, cet. ke-2, 1964, juz 8, hlm. 1

${ }^{24}$ Ibnu Manzhūr, Lisān..., juz 12, hlm. 446 
Di zaman jahiliyah, masa sebelum Islam, kabilah-kabilah Arab jika menang dalam berperang akan mengambil ganimah (harta yang dapat dibawa, tawanan, dan tanah) dan membagi-bagikannya kepada orang yang ikut serta berperang. Ketua mereka mendapat bagian yang besar. Setelah Islam, adat kebiasaan yang sudah berjalan jauh sebelum Islam ini dikukuhkan. Ajaran Islam menyatakannya sebagai harta yang halal, dengan perbaikan-perbaikan tertentu berkenaan dengan cara pembagiannya. Aturan tentang ganimah ini dijelaskan dalam ayat berikut:

"Ketabuilah, sesunggubnya apa saja yang dapat kalian peroleh sebagai ganimah (ghanimtum), maka sesunggubnya seperlimanya untuk. Allah, Rasul, kerabat Rasul, anak-anak yatim, orang-orang miskin dan ibnu sabil, jika kalian beriman kepada Allab dan kepada apa yang Kami turunkan kepada hamba Kami (Muhammad) di hari furqan, yaitu hari bertemunya dua pasukan. Dan Allah Maha Kuasa atas segala sesuatu." (QS. Al-Anfäl [8]:41).

Ayat ini berbicara tentang ganimah, sebagai perincian pesan ayat pertama QS. al-Anfal. Pada ayat pertama mereka bertanya tentang al-anfäl dan dijawab bahwa al-anfäl adalah milik Allah, dan Rasul Saw diberi wewenang untuk membaginya atas petunjuk Allah. Maka ayat ini mengemukakan petunjuk pembagian tersebut. ${ }^{25}$ Yaitu bahwa seperlima ganimah itu dibagi menjadi lima bagian: (1) untuk Allah dan Rasul-Nya, (2) kerabat Rasul, (3) anakanak yatim, (4) orang-orang miskin dan (5) ibnu sabil. Pernyataan Allab dan Rasul yang dimaksud adalab untuk Rasul, karena penyebutan Allab dalam ayat ini sebagai penghormatan bagi Rasul yang menjadi utusan-Nya atau bagian seperlima ada yang harus diikhlaskan di jalan Allah. Bagian untuk Rasul diserabkan kepada beliau sesuai dengan kemauannya; bisa dimanfaatkan untuk beliau sendiri atau diserabkan kepada umatnya. ${ }^{26}$ Yang dimaksud kerabat Rasul adalah anak-anak Muslim yang telah ditinggal mati orang tua mereka dan mereka yang kekurangan. Orang-orang miskin adalah orang-orang Muslim yang membutubkan bantuan. Ibnu Sabil adalab orang Islam yang bepergian kehabisan bekal. Sedang empat perlima dari harta rampasan perang untuk para serdadu yang mendapatkan rampasan perang itu.

Pembagian ganimah tersebut paling banyak diberikan kepada serdadu muslim yang ikut pertempuran. Hal ini menunjukkan bahwa Islam sangat menghargai kerja dan

25 Shihab, Tafsir..., vol. 5, hlm. 425

${ }^{26}$ Al-Qasimi, Tafsìr al-Qāsimi, jilid VIII, Mesir: Isa al-Bābi al-Halabi, t.t., hlm. 300 
pengorbanan mereka demi kejayaan Islam, sekaligus memberi motivasi kepada mereka untuk memenangkan setiap pertempuran.

Pembagian harta rampasan perang ini mempunyai hikmah yang sangat penting bagi negara yang mengatur segala dana yang masuk untuk kepentingan masyarakat secara luas. Kepentingan-kepentingan itu meliputi: kepentingan umum seperti menampakkan syiar Islam, untuk membiayai keperluan pimpinan umat dan kepala negara, yaitu Rasul, kerabat Rasul yang giat dan ikhlas membela perjuangan dan ketinggian Rasul, dan untuk membantu orangorang lemah. ${ }^{27}$

Mayoritas ulama Sunni mempersempit makna dan menafsirkan kata ganimah -atau ganimtum dalam ayat di atas- semata sebagai hasil rampasan perang. Karena itu, bagi kaum Sunni, karena perang tidak terjadi maka kemudian khumus (perlimaan) hanya disebut ketika mereka mengkaji teori sumber pendapatan negara dalam kajian ekonomi makro Islami. Sementara mazhab Ja'fari -yang dianut kaum Syi'ah- memahami ganimah dalam ayat di atas tidak sekedar "harta rampasan perang". Menurut Al-Allamah alThabā'thaba'i ayat di atas mengandung hukum yang abadi (berlaku kapan pun) sebagaimana hukum-hukum yang dikandung Al-Qur'an lainnya. Hukum yang dikandung ayat ini mencakup apa saja yang dinamai ganm dan ganimah, baik itu ganimah perang yang diambil dari kaum kafir maupun lainnya yang secara etiomologi dapat disebut ganimah seperti keuntungan usaha, apa yang didapat dari menyelam di laut (mutiara) dan apa yang dikeluarkan dari bumi berupa harta karun dan barang tambang. Meskipun ayat ini turun dalam konteks ganimah perang tapi konteks ini tidak mengikat. ${ }^{28}$

Maka, berdasar kajian Al-Qur'an, hadis dan sejarah, mazhab Ja'fari menyimpulkan bahwa ganimah adalah "apa yang diperoleh seseorang atau sekelompok orang lewat usaha”, sehingga ganimah juga mencakup harta-harta sebagai berikut: harta rampasan perang, barang tambang, harta karun yang mencapai nisab, hasil penyelaman barang berharga, harta milik yang bercampur harta haram, dan kelebihan pendapatan selama satu tahun yang

${ }^{27}$ Muhammad Rasyīd Ridhā, Tafsìr al-Qurān al-Hakim, Kairo: Dar al-Manār, 1373, juz X, hlm. 8

28 Al-Thabā'thaba'i, "Tafsīr al-Mīzān”, tafsir QS. Al-Anfâl [8]:41, dalam CD Room, Jame Quran Program, Muassasah Nasyr Hadīts Ahl al-Bait, t.t. 
disebut sebagai mata pencarian (profesi). ${ }^{29}$ Terlepas dari perbedaaan pendapat mengenai makna ganimah dalam Al-Qur'an, yang jelas bahwa kaum miskin berhak memperoleh atas hal tersebut. Ini menunjukkan bahwa ganimah dapat dipandang sebagai cara Al-Qur'an mengatasi kemiskinan dan memberdayakan kaum miskin dalam persoalan ekonomi. Di sisi lain, pembagian ini menunjukkan peran dan tanggungjawab negara dalam penanggulan kemiskinan dan pemberdayaan kaum miskin sehingga sebagian dari dana yang masuk ke negara harus dialokasikan untuk mereka.

Sedangkan fa'i adalah harta (rampasan perang) yang diperoleh dari musuh tanpa terjadinya pertempuran. Harta fa'i dapat muncul melalui banyak cara, seperti melalui perdamaian, jizyah, dan kharaj (pajak tanah). Harta fa' $i$ dapat juga timbul karena seorang musuh memasuki wilayah Islam membawa harta, kemudian hartanya diambil oleh umat Islam, atau terjadi karena tentara musuh lari meninggalkan harta bendanya sebelum terjadinya peperangan. Ketentuan tentang fa'i ini disebutkan Allah Swt dalam ayat berikut ini:

"Apa saja fay yang diberikan Allah kepada Rasul-Nya yang berasal dari penduduk kota-kota maka adalah untuk Allah, Rasul, kerabat Rasul, anakanak yatim, orang-orang miskin dan orang-orang yang dalam perjalanan, supaya harta itu jangan hanya beredar di antara orang-orang kaya saja di antara kalian. Apa yang diberikan Rasul kepadamu maka terimalah dia. Dan apa yang dilarangnya bagimu maka tinggalkanlah; dan bertakwalah kepada Allah. Sesungguhnya Allah sangat keras hukuman-Nya." (QS. Al-Hasyr [59]:7)

Ayat ini berbicara tentang ketentuan fa'i, dimana pembagiannya adalah untuk Allah, Rasul, kaum kerabat, anak-anak yatim, orang miskin, dan orangorang yang sedang dalam perjalanan. Menurut Sa'id Hawa, pendistribusian ini ditempuh agar harta kekayaan tersebut tidak menjadi milik segelintir orang kaya yang dapat mereka pergunakan sesuka mereka tanpa ada sedikit pun bagian yang diberikan kepada kaum fakir miskin dan orang-orang yang membutuhkan lainnya. ${ }^{30}$

Salah satu kelompok yang berhak memperoleh harta ganimah dan fa'i itu adalah kaum miskin. Bagian orang miskin sama antara pembagian dalam

\footnotetext{
29 Miqdad Turkan, "Khumus: Hukum dan Peranannya", http://aljawad.tripod.com/arsipbuletin/ khumus.htm, diakses 23 Agustus 2014

${ }^{30}$ Sa īid Hawa, al-Asās fì al-Tafsìr, Kairo: Dār al-Salām, cet ke-2, 1989, juz 4, hlm. 5822
} 
harta rampasan yang diperoleh melalui peperangan maupun harta rampasan yang diperoleh tidak melalui peperangan. Perbedaannya pada bagian empat perlimanya, dimana dalam ganimah dibagikan kepada para serdadu yang berperang, sedangkan fa'i diberikan kepada Rasul selaku pemimpin negara dan pemimpin agama diberi hak untuk membelanjakan empat perlima harta rampasan perang yang diperoleh tanpa melalui peperangan itu menurut pertimbangannya sesuai dengan petunjuk Allah.

Karena itu pendistribusian ganimah dan fa'i kepada mereka dapat dipahami sebagai bagian dari upaya Islam untuk memberdayakan mereka secara ekonomi.

\section{Larangan monopoli (ihtikār) dan menimbun harta (iktināz)}

Dalam bahasa Arab, monopoli disebut dengan ibtikār. Dalam kamus Lisān al-'Arab, ibtikēr diartikan "menimbun dan menahan makanan atau kebutuhan pokok karena menunggu harga tinggi". ${ }^{31}$ Al-Sayyid Sabiq dalam Fiqh al-Sunnah menyatakan ibtikear sebagai membeli suatu barang dan menyimpannya agar barang tersebut berkurang di masyarakat sehingga harganya meningkat sehingga manusia akan mendapatkan kesulitan akibat kelangkaan dan mahalnya harga barang tersebut. ${ }^{32}$

Fathi ad-Duraini mendefinisikan ibtikearr dengan tindakan menyimpan harta, manfaat atau jasa, dan enggan menjual dan memberikannya kepada orang lain yang mengakibatkan melonjaknya harga pasar secara drastis disebabkan persediaan barang terbatas atau stok barang hilang sama sekali dari pasar, sementara rakyat, negara, ataupun hewan (peternakan) amat membutuhkan produk, manfaat, atau jasa tersebut. Ibtikēr menurut ad-Duraini, tidak hanya menyangkut komoditas, tetapi manfaat suatu komoditas dan bahkan jasa dari pembeli jasa dengan syarat, embargo yang dilakukan para pedagang dan pemberi jasa ini bisa memuat harga pasar tidak stabil, padahal komoditas, manfaat, atau jasa tersebut sangat dibutuhkan oleh masyarakat, negara, dan lain-lain. Misalnya, pedagang gula pasir di awal Ramadhan tidak mau menjual barang dagangannya, karena mengetahui bahwa pada minggu terakhir bulan Ramadhan masyarakat sangat membutuhkan gula untuk

\footnotetext{
${ }^{31}$ Ibn Mandzūr, Lisān ..., juz 4, hlm. 208

32 Al-Sayyid Sābiq, Fiqh al-Sunnah, Mesir: al-Fath li al-I'lām al-'Arabiy, cet ke-11, 1994, juz 3, hlm. 176
} 
menghadapi lebaran. Dengan menipisnya stok gula di pasar, harga gula pasti akan naik. Ketika itulah para pedagang gula menjual gulanya, sehingga pedagang tersebut mendapat keuntungan (profit) yang berlipat ganda. ${ }^{33}$

Istilah ibtikār dalam Al-Qur'an tidak digunakan, tetapi tidak berarti Kitab Suci ini tidak menyinggung dan mempersoalkan ibtikearr (monopoli). Setidaknya masalah ibtikearr dapat kita peroleh larangannya secara umum dari firman Allah Swt:

“Apa saja fay yang diberikan Allah kepada Rasul-Nya yang berasal dari penduduk kota-kota maka adalah untuk Allah, Rasul, kerabat Rasul, anakanak yatim, orang-orang miskin dan orang-orang yang dalam perjalanan, supaya harta itu jangan hanya beredar di antara orang-orang kaya saja di antara kalian. Apa yang diberikan Rasul kepadamu maka terimalah dia. Dan apa yang dilarangnya bagimu maka tinggalkanlah; dan bertakwalah kepada Allah. Sesungguhnya Allah sangat keras hukuman-Nya. (QS. Al-Hasyr [59]:7)

Kalimat "supaya harta itu jangan hanya beredar di antara orang-orang kaya saja di antara kalian" menunjukkan larangan monopoli, yakni terkonsentrasinya kekayaan di kalangan orang kaya saja. Menurut Sa’̄id Hawa, ayat ini menunjukkan bahwa salah satu tujuan yang hendak dicapai oleh aturan Islam mengenai harta adalah tidak adanya konsentrasi harta kekayaan di tangan orang-orang kaya saja. Oleh sebab itu Allah mengharamkan riba, monopoli (ibtikēr), penimbunan (iktināa) dan menetapkan hukum waris. ${ }^{34}$

Larangan monopoli ini dipertegas oleh sabda Nabi Saw dalam banyak hadis, diantaranya:

"Dari Abu Hurairah bahwa Rasulullah Saw bersabda: Barangsiapa yang melakukan monopoli dengan tujuan agar harga naik atas kaum Muslim, maka dia telah melakukan dosa" (HR. Ahmad). ${ }^{35}$

"Umar bin Khattab berkata: Saya mendengar Rasulullah Saw bersabda: Barangsiapa yang melakukan monopoli makanan atas kaum Muslim Allah akan menimpakan kepadanya penyakit dan kebangkrutan" (HR. Ibnu Majah). ${ }^{36}$

\footnotetext{
33 Abdul Aziz Dahlan (ed), Ensiklopedi Hukum Islam, Jakarta: PT. Ikhtiar Baru, 1996, hlm. 655

${ }^{34}$ Hawa, al-Asās ..., juz 4, hlm. 5822

35 Ahmad bin Hanbal, "Musnad Ahmad", hadis no. 8263, Program Hadis Mausü'at al-Hadits alSyarif, edisi 6.2, Harf Information Technology Company, 1998-2000
} 
"Dari Ibnu Umar bahwa Nabi Saw bersabda: Barangsiapa yang melakukan monopoli makanan selama empat puluh malam, sungguh dia telah berlepas diri dari Allah Ta'ala dan Allah Ta'ala telah berlepas diri darinya." (HR. Ahmad). ${ }^{37}$

Sedangkan menimbun harta dalam bahasa Arab disebut iktināz atau kanz al-mäl. Istilah ini dipahami dari firman Allah Swt berikut ini:

"Hai orang-orang yang beriman, sesungguhnya sebagian besar dari orangorang alim Yahudi dan rahib-rahib Nasrani benar-benar memakan harta orang dengan jalan yang batil dan mereka menghalang-halangi (manusia) dari jalan Allah. Dan orang-orang yang menyimpan (yaknizüna) emas dan perak dan tidak menginfakkannya pada jalan Allah, maka gembirakanlah mereka dengan siksa yang pedih" (QS. al-Taubah [9]:34)

Secara bahasa, iktināz, sebagaimana dikatakan al-Rāgib al-Isfahānī, adalah ja'l al-māl ba'dhabu 'alà ba'dh wa hifžbubu (menumpuk dan menyimpan harta). ${ }^{38}$ Pada saat diharamkan, emas dan perak menjadi alat tukar dan standar bagi tenaga, jasa atau manfaat suatu harta. Atas dasar itu, larangan penimbunan emas dan perak itu juga terkait dengan fungsinya sebagai alat tukar. Artinya, larangan itu juga mencakup larangan terhadap penimbunan uang secara umum. Karena itu, iktinäz dapat diartikan dengan menahan harta (dana), menahannya, menjauhkan dari peredaran dan membiarkannya menganggur dan tidak berputar dalam transaksi yang bermanfaat bagi masyarakat umum.

Ada kesamaan antara iktināz dan ibtikār dalam hal menumpuk dan menahan kekayaan. Hanya saja iktinäz terdorong oleh keengganan untuk menginfakkan (menginvestasikan) harta pada hal-hal yang mendatangkan kemaslahatan umum, sedang ihtikear terdorong oleh keinginan untuk meraup keuntungan besar, di mana harta (barang-barang kebutuhan masyarakat) yang ditahan itu akan dilepas ke pasar pada saat harganya naik. Tapi dampak dari keduanya sama; menimbulkan kerugian bagi orang banyak. ${ }^{39}$

Menurut al-Zamakhsyari, orang-orang yang menyimpan/menimbun emas dan perak dalam ayat tersebut adalah dua kemungkinan. Pertama, Para pendeta Yahudi dan Nasrani sesuai dengan teks permulaan ayat yang

36 Ibn Mājah, "Sunan Ibn Mājah", hadis no. 2146, Program Hadis Mausū'at al-Hadìts al-Syarif, edisi 6.2, Harf Information Technology Company, 1998-2000

${ }^{37}$ Ahmad bin Hanbal, "Musnad ...", hadis no. 4648

38 Al-Isfahānī, Mufradāt ..., hlm. 460

${ }^{39}$ Badruzzaman, Teologi ..., hlm. 193 
menyebut abbār (ulama Yahudi) dan rubbān (ulama Nashrani) yang punya dua kebiasaan tercela, yaitu suka mengambil uang suap alias sogok (suka memakan harta manusia dengan cara batil) dan bakhil (tak mau menginfakan harta di jalan Allah). Jadi firman Allah Swt yang menyebut orang-orang (para pendeta) yang suka menyimpan uang (emas dan perak) mempersatukan atau mempertemukan kedua sifat buruk tersebut. Kedua, Kaum muslimin yang menyimpan atau menimbun uang tanpa menginfakkannya di jalan Allah. ${ }^{40}$

Imam al-Bukhari meriwayatkan dari Zaid bin Wahab tentang perbedaan pendapat Muawiyah bin Abi Sufyan dengan Abu Dzar tentang ayat di atas. Muawiyah berkata, "Ayat ini bukan untuk kita, melainkan ayat ini hanya untuk Ahli Kitab." Abu Dzar membantah dengan mengatakan, "Sungguh, ayat ini untuk kita dan mereka." Muawiyah lalu melaporkan Abu Dzar kepada khalifah Usman. Lalu khalifah memanggil Abu Dazar ke Madinah, dan berlangsunglah peristiwa seperti yang diceritakan dalam riwayat tersebut.

Selain itu dapat kita pahami bahwa sekali pun ayat itu diturunkan tentang ahli kitab, namun kaum Muslim juga termasuk sasaran keumuman ayat di atas, sebagaimana dipahami dari awal ayat tersebut yang berbunyi: yā ayyuhal ladzৃina ämanū (bai orang-orang yang beriman). Terhadap orang-orang Mukmin yang menyimpan uangnya tanpa keperluan itu Rasulullah Saw bersabda: "Siapa saja yang meninggalkan (mati dalam keadaan menyimpan) yang kuning (uang emas) dan yang putih (uang perak), maka dia diseterika dengannya (di neraka kelak)." (HR. Bukhari). Dalam riwayat Țabrānī dengan redaksi yang lebih jelas, yaitu: "Tidaklah seseorang hamba mati dalam keadaan meninggalkan emas dan perak melainkan diseterika dengannya."

Dalam ayat di atas, Allah Swt mengancam para penimbun emas dan perah (harta) dengan azab yang pedih. Bahkan Allah Swt menerangkan bentuk siksanya secara jelas mengingat bahayanya tindakan kriminal tersebut bagi dinamika ekonomi, yakni dengan membakar dahi, lambung, punggung mereka, seolah lempengan-lempengan emas dan perah yang disimpannya tadi dijadikan oleh Allah Swt sebagai seterika. Menurut Al-Qurțubī, diseterikanya wajah untuk menelanjangi keburukan pelaku serta menunjukkan seramnya yang tersiksa. Sedangkan diseterikanya punggung dan lambung menunjukan betapa

40 Abū al-Qāsim Mahmūd bin 'Amr bin Ahmad al-Zamakhsyari, al-Kasysyāy 'an Haqaaiq Ghawāmidh al-Tanzìl, Beirut: Dār al-Kitāb al-‘Arabi, cet ke-3, 1407 H, juz 2, hlm. 257

Volume VT/Edisi 1/Mei 2015 
pedih dan menyakitkan siksaan dari tindakan menyimpan emas dan perak itu. Oleh karena itulah, siksaan tubuh itu dikhususkan kepada tiga bagian itu. ${ }^{41}$

Ibtikār dan iktinā̃ juga termasuk cara memperoleh harta secara batil dan tindakan aniaya sekelompok orang (orang kaya) terhadap kelompok lain (orang miskin). Dan hal ini dilarang Allah Swt dalam Al-Qur'an (QS. al-Nisā’ [4]:29; al-Baqarah [2]:279). Ibtikearr dan iktinäz dilarang oleh Al-Qur'an karena menyebabkan modal atau harta menjadi mati dan tidak dikembangkan dalam bentuk usaha. Perilaku iktināz bertolak belakang dengan tujuan Allah Swt dalam menganugerahkan harta kepada hamba-Nya, yaitu agar harta tersebut bermanfaat bagi orang lain dan tidak boleh berputar (terakumulasi) di kalangan orang kaya saja (QS. al-Hasyr [59]:7).

Maka dapat dipahami, jika Al-Qur'an melarang ibtikēr dan iktinär. karena keduanya dapat menimbulkan bahaya besar pada perekonomian negara. Bahaya yang ditimbulkan oleh penimbunan harta akan mempengaruhi perekonomian karena sekiranya uang, harta, atau barang tidak disimpan dan tidak ditahan, tentu ia ikut andil dalam usaha-usaha produktif, misalnya menjadi modal dalam usaha produktif yang baru. ${ }^{42}$ Usaha baru ini akan menciptakan banyak lapangan kerja baru, yang dapat mengurangi masalah pengangguran, sehingga meningkatkan income perkapita dan daya beli masyarakat, disamping menciptakan pertumbuhan ekonomi masyarakat dan negara. Dengan kata lain, penimbunan harta berarti menghambat bahkan menghentikan arus jasa dan barang. Dan tentunya jika itu terjadi berarti dinamika ekonomi terhenti. Karena itu, ihtikār (monopoli) dan iktināz (penimbunan harta) selain berlawanan dengan sunnatullah, juga merupakan kejahatan sosial.

Dengan demikian, larangan ihtikār dan iktināz dapat dipahami sebagai cara Al-Qur'an memberdayakan kaum fakir dan miskin, karena harta tersebut didistribusikan dan digunakan untuk kepentingan masyarakat banyak, terutama disalurkan kepada kaum fakir dan miskin yang sangat membutuhkannnya, baik dalam bentuk bantuan langsung maupun dalam bentuk usaha-usaha produktif sehingga mereka terlepas dari kemiskinan.

\footnotetext{
41 al-Qurthubi, al-Jāmi'..., juz 8 hal 129

42 Ahmad Muhammad Al-Assal dan Fathi Ahmad Abdul Karim, Sistem, Prinsip dan Tujuan Ekonomi Islam, Bandung: Pustaka Setia, 1999, hlm. 100-101
} 
Beberapa model pemberdayaan di atas dapat dibagi menjadi dua kelompok. Pertama, langkah-langkah yang bersifat struktural, dan kedua yang bersifat kultural. Langkah struktural lebih ditekankan kepada lembaga khusus yang menanganinya agar berjalan dengan baik, sedangkan langkah kultural lebih ditekankan pada individu, baik individu yang diharapkan menjadi salah satu subjek pengentasan kemiskinan dan pemberdayaan kaum fakir dan miskin maupun yang menjadi objeknya. Perintah mengeluarkan zakat, memberi makan, pembagian ganiumah dan fa'i dan larangan monopoli (ibtikär) dan menimbun harta (iktināa) termasuk kelompok pertama. Sedangkan perintah bekerja dan berinfak termasuk kelompok kedua. Bekerja ditekankan pada kaum miskin, sedangkan infak ditekankan pada kaum kaya. Pada langkah struktural maupun kultural, keterlibatan pemerintah sangat diperlukan, bahkan dipandang sebagai sebuah keniscayaan.

\section{Kesimpulan}

Kaum fakir dan miskin merupakan masalah sosial yang kompleks serta multidimensi. Menghadapi persoalan sosial yang akut ini, Al-Qur'an menawarkan beberapa prinsip dalam pemberdayaan kaum fakir dan miskin, yaitu: Pertama, prinsip ta āwün, prinsip kerjasama dan sinergi di antara berbagai pihak, baik pemerintah, lembaga zakat, ulama, organisasi Islam dan berbagai kelompok masyarakat secara umum. Kedua, prinsip syūrā, prinsip musyawarah di antara pemerintah dan pihak-pihak yang terkait dengan persoalan pemberdayaan kaum fakir dan miskin dalam satu program kepeduliaan terhadap masalah kemiskinan dengan mengidentifikasi masalah-masalah yang menyebabkan kemiskinan serta merumuskan langkah-langkah penanggulangan yang berkesinambungan.

Persoalan pemberdayaan fakir miskin dalam pandangan Al-Qur'an terkait erat dengan masalah pemanfaatan dan pendistribusian harta. Karena itu, upaya pembebasan dan pemberdayaan fakir dan miskin terlebih dahulu harus melihat bagaimana ketentuan Al-Qur'an menyangkut pemanfaatan dan distribusi harta. Dari ayat-ayat Al-Qur'an yang berbicara tentang harta (māl, amwāl), secara garis besar dapat diambil dua ketentuan. Pertama berupa perintah dan anjuran dan yang kedua berupa larangan. Dari dua ketentuan ini, ada beberapa model dan langkah yang ditempuh Al-Qur'an dalam mengentaskan kemiskinan dan memberdayakan kaum fakir dan miskin, adalah 
perintah bekerja, perintah memberi makanan pokok, perintah berinfak, perintah mengeluarkan zakat, pemberian sebagian dari harta warisan, pembagian ganimah dan $f a '$, dan larangan monopoli (ibtikär) dan menimbun harta (iktinā̄s).

Beberapa model pemberdayaan di atas dapat dibagi menjadi dua kelompok; langkah-langkah yang bersifat struktural dan yang bersifat kultural. Langkah struktural lebih ditekankan kepada lembaga khusus yang menanganinya agar berjalan dengan baik, sedangkan langkah kultural lebih ditekankan pada individu, baik individu yang diharapkan menjadi salah satu subjek pengentasan kemiskinan dan pemberdayaan kaum fakir dan miskin maupun yang menjadi objeknya. Perintah mengeluarkan zakat, memberi makan, pembagian ganimah dan fä dan larangan monopoli (ibtikär) dan menimbun harta (iktinās) termasuk kelompok pertama. Sedangkan perintah bekerja dan berinfak termasuk kelompok kedua. Bekerja ditekankan pada kaum miskin, sedangkan infak ditekankan pada kaum kaya. Pada langkah struktural maupun kultural, keterlibatan pemerintah sangat diperlukan, bahkan dipandang sebagai sebuah keniscayaan. 


\section{DAFTAR PUSTAKA}

al-Assal, Ahmad Muhammad, dan Fathi Ahmad Abdul Karim, Sistem, Prinsip dan Tujuan Ekonomi Islam, Bandung: Pustaka Setia, 1999

Badruzaman, Abad, Teologi Kaum Tertindas Kajian Tematik Ayat-ayat Mustadh'afin dengan Pendekatan Keindonesiaan), Yogyakarta: Pustaka Pelajar, 2007

Beik, Irfan Syauqi, Economic Role of Zakat in Reducing Poverty and Income Inequality: A Case Study in the Province of DKI Jakarta, Indonesia, Jerman: La,bert Academic Publishing, 2013

Dahlan, Abdul Aziz, (ed), Ensiklopedi Hukum Islam, Jakarta: PT. Ikhtiar Baru, 1996

Ghanim, Husein, al-Iqtishäd al-Islämy: Thabīatuhu wa Majälatuhu, Kairo: Dār al Wafā', Cet. Ke-I, 1411-1991

Hafidhuddin, Didin, dkk, Fiqh Zakat Indonesia, Jakarta: BAZNAS, cet ke-1, 2013

-----------, Zakat dalam Perekonomian Modern, Jakarta: Gema Insani Press, 2002

Hawa, Sa ${ }^{c} \overline{1} d$, al-Asās fì al-Tafsìr, Kairo: Dār al-Salām, cet ke-2, 1989

Ibn Manzhūr, Jamāl al-Dīn, Lisān al-'Arab, Beirut: Dār Shādir, cet ke-3, 1414 $\mathrm{H}$

al-Isfahāni, al-Rāgib, Mufradāt fì Garìb al-Qurān, Beirūt: Dār al-Ma'rifah, t.th.

al-Jurjāni, 'Ali bin Muhammad bin 'Ali al-Zain al-Syarîf, Kitāb at-Ta'rîfät, Beirut:

Dār al-Kutub al-'Ilmiyyah, cet ke-1, 1983

Mintarti, et al, Indonesia Zakat and Development Report, Jakarta: IMZ, 2012

Prijono, Ony S. dan A. M. W. Pranarka, Pemberdayaan Konsep, Kebijakan dan Implementasi, Jakarta: Center for Strategic and International Studies, 1996

Program Hadis Mausū'at al-Hadìts al-Syarif, edisi 6.2, Harf Information Technology Company, 1998-2000

al-Qardhawi, Yusuf, Musykilat al-Faqr wa Kaifa 'Alajahā al-Isläm, Beirut: Mu'assasah al-Risālah, 1985

al-Qasimi, Tafsìr al-Qāsimi, Mesir: Isa al-Bābi al-Halabi, t.tt.

al-Qurthubī, Abū Abdillah Mụ̣ammad bin Ahmad bin Abī Bakr bin Farh alAnshārī al-Khazrajī Syams al-Dīn, al-Jāmi’ li Abkām al-Qurān, tahqīq Ahmad al-Bardūnī wa Ibrāhīm Athfīsy, Kairo: Dār al-Kutub alMishriyyah, cet ke-2, 1964

Ridhā, Muhammad Rasyīd, Tafsīr al-Qurān al-Hakìm, Kairo: Dar al-Manār, 1373

Sābiq, al-Sayyid, Figh al-Sunnah, Mesir: al-Fatḥ li al-I làm al-'Arabiy, cet ke-11, 1994 
Pemberdayaan Ekonomi Fakir Miskin

Shihab, M. Quraish, Tafsir al-Misbah; Pesan, Kesan dan Keserasian Al-Qur'an, Jakarta: Penerbit Lentera Hati, cet. I, 2002

----------, Membumikan Al-Qur'an, Bandung: Mizan, 1992

al-Thabā'thaba'i, "Tafsīr al-Mīzān", tafsir QS. Al-Anfâl [8]:41, dalam CD

Room, Jame Quran Program, Muassasah Nasyr Hadīts Ahl al-Bait, t.t.

Turkan, Miqdad, "Khumus: Hukum dan Peranannya", http://aljawad.tripod.com/arsipbuletin/ khumus.htm, diakses 23 Agustus 2014

Undang-undang Republik Indonesia Nomor 23 Tahun 2011 tentang Pengelolaan Zakat

al-Zamakhsyari, Abū al-Qāsim Mahmūd bin 'Amr bin Ahmad, al-Kasysyā̃f 'an Haqāiq Ghawāmidh al-Tanzill, Beirut: Dār al-Kitāb al-'Arabi, cet ke-3, $1407 \mathrm{H}$

http://www.imz.or.id/new/article/1131/zakat-masyarakat-dan-negara-dalampengentasan-kemiskinan-2/, diakses 6 Oktober 2014 